\title{
Circulating cell-free DNA as a biomarker in the diagnosis and prognosis of colorectal cancer
}

\author{
Isadora Bernardo David de Oliveira ${ }^{1 *}$, Rosario Dominguez Crespo Hirata ${ }^{1}$
}

${ }^{1}$ School of Pharmaceutical Sciences, University of Sao Paulo, Sao Paulo, Brazil

\begin{abstract}
Colorectal cancer (CRC) is a disease without evident clinical symptoms in early stages, leading to late diagnosis and disease management. Current diagnostic and prognostic tools require invasive procedures and circulating molecular biomarkers fail to have optimal sensitivity and specificity. Circulating biomarkers with high clinical performance may be valuable for early diagnosis and prognosis of CRC. The purpose of this review was to investigate the application of circulating cell-free DNA (ccfDNA) in CRC diagnosis and prognosis and the analytical methods used in blood samples in articles published between 2005 and 2016. Based on specific inclusion and exclusion criteria, 26 articles were selected. Most studies used ccfDNA quantification as the molecular biomarker. The analytical method was mainly based on the quantitative polymerase chain reaction (qPCR). Biomarkers based on aberrantly methylated genes $(\mathrm{n}=6)$ and ccfDNA integrity/fragmentation $(\mathrm{n}=2)$ were also used for the CRC diagnosis. The CRC prognosis used the detection of oncogene mutations, such as KRAS and BRAF, in ccfDNA. Significant differences were found in variables among the studies revealing potential bias. ccfDNA quantification as a diagnostic biomarker for $\mathrm{CRC}$ has promising results but it lacks clinical specificity since other diseases present a similar increase in ccfDNA content. However, increasing research in the epigenomic field can lead the way to a clinically specific biomarker for the CRC early diagnosis. As for the analytical method, qPCR and derivatives seem to be a perfectly valid technique. The use of ccfDNA quantification in CRC prognosis seems promising. The attempt to use the ccfDNA quantification in clinical practice may reside in the prognosis using a $\mathrm{qPCR}$ technique.
\end{abstract}

Keywords: Colorectal Neoplasms/diagnosis. Colorectal cancer. Circulating cell-free DNA. ccfDNA. Prognosis. Diagnosis. Biomarkers. Neoplastic Cells/circulating.

\section{INTRODUCTION}

Cancer is one of the leading causes of morbidity and mortality with 14 million new cases and 8.2 million related deaths in 2012 (Ferlay et al., 2015). Colorectal cancer $(\mathrm{CRC})$ is the third most prevalent type of cancer with 1.4 million $(9.7 \%)$ cases diagnosed worldwide each year (Ferlay et al., 2015).

The CRC is a solid tumor with slow progression over the years without evident clinical symptoms in early stages, which causes difficulty for an early diagnosis. CRC symptoms include an anemia of unknown origin, changes in the intestinal habits (diarrhea or constipation), abdominal discomfort with flatulence or cramps and blood

*Correspondence: I. B. D. Oliveira. Faculdade de Ciências Farmacêuticas, Universidade de São Paulo. Avenida Professor Lineu Prestes, 580, CEP: 05508-900, Butantan, São Paulo, Brasil. Tel.: +55 113110 3458. E-mail: isadorabdo@gmail.com on the feces (INCA, 2016; American Cancer Society, 2016). Usual diagnostic and screening exams for the $\mathrm{CRC}$ are based on blood tests in stool samples, such as the guaiac-based fecal occult blood test (gFOBT), the fecal immunochemical test (FIT) and the stool DNA test, and on an imaging analysis such as sigmoidoscopy, colonoscopy, double-contrast barium enema and the CT colonoscopy and tumor biopsy derived from colonoscopy (American Cancer Society, 2016).

Analysis of tumor markers in plasma, such as carcinoembryonic antigen (CEA), cancer antigen (CA) 19-9 and tissue polypeptide specific antigen (TPS) have been used for CRC management. The CEA, is a high molecular weight glycoprotein involved in cell adhesion, apoptosis and immunity, used in clinical practice. The CA 19-9 is a glycoprotein with high molecular weight released to the blood and is observed in gastrointestinal tract tumors. TPS is a single conjugated polypeptide chain 
formed in the S and G2 phase of the molecular cycle and released to cells after mitosis (Swiderska et al., 2014). Unfortunately, these biomarkers did not demonstrate sufficient sensitivity and specificity. There is an urgent search for more sensitive and specific biomarkers for CRC (Swiderska et al., 2014; Nicholson et al., 2015).

Molecular biomarkers in blood samples are proposed for diagnosis and prognosis of the $\mathrm{CRC}$, such as circulating free DNA (ccfDNA) (Yörüker et al., 2016). ccfDNA is the DNA present in plasma directly released from viable cells or activated macrophages, or released during cell death by mechanisms of the apoptosis or necrosis (Yörüker et al., 2016) (Figure 1). Moreover, tumor cells also release significant amounts of DNA in the blood circulation, which is incorporated into the circulating DNA pool (Diaz Jr., Bardeli, 2014). The measurement of ccfDNA has been proposed as a biomarker of the tumor burden and it is potentially useful for diagnosis, prognosis and therapy management of the CRC (Diaz Jr., Bardeli, 2014). Moreover, the analysis of CRC mutations in circulating DNA could represent an "alternative biopsy", mainly for therapy monitoring and tumor recurrences. (Diaz Jr., Bardeli, 2014).

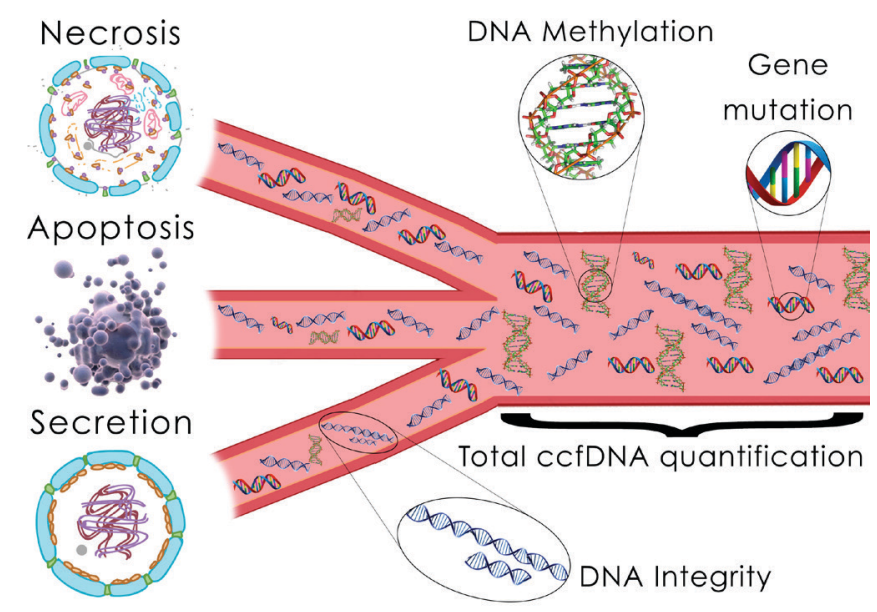

FIGURE 1 - Schematic mechanisms of release and ccfDNA characteristics.

Aberrant DNA methylation (metDNA) has also been found to be associated with the CRC disease (Lao, Grady, 2011). Hypermethylation of the $\mathrm{CpG}$ islands located at the promoter region causes gene silencing, while hypomethylation increases gene transcription. Studies have already verified a few genes frequently methylated in the CRC (Lao, Grady, 2011). There might be a clinical application for the detection of those methylated genes.

Current clinical prognosis biomarkers include microsatellite instability (MSI) and the study of mutations in oncogenes. MSI status can be verified by immunohistochemistry and by PCR amplification (Morris, Kopetz, 2013). High MSI indicates a good prognostic correlating to the initial stages of the disease, smaller recurrence rates after resection of the primary tumor (Morris, Kopetz, 2013).

The CRC-associated mutations within the protooncogene KRAS are the most studied. KRAS mutations lead to an activated state of the RAS proteins, which stimulate the proliferation by two distinct pathways $\mathrm{PI} 3 \mathrm{~K} / \mathrm{PTEN} / \mathrm{AKT}$ and RAF/MEK/ERK. These mutations are present in stage IV of the disease and in different metastases representing an unfavorable survival outcome (Morris, Kopetz, 2013). In addition, mutations in KRAS affect the effectiveness of recent anti-epidermal growth factor receptor (EGFR) therapies (Morris, Kopetz, 2013).

Mutations in the oncogene $B R A F$ lead to constitutive activation of the MAPK pathway. Consequently, $B R A F$ mutations relate to a worse prognosis indicating as well non-responsiveness to anti-EGFR therapies (Morris, Kopetz, 2013). Mutations in the oncogene PIK3CA lead to apoptosis resistance, cell proliferation and promotion of cell migration. However, the relationship of PIK3CA mutations with the prognosis is still unclear. Mutations on the tumor suppression gene TP53 also have limited relevant data on CRC disease management.

Considering the potential relevance of ccfDNA for CRC management, this review approaches the findings of clinical studies published between 2005 and 2016 that investigated the application of ccfDNA on diagnosis and prognosis of CRC and the analytical methods used for ccfDNA detection in blood samples. More diagnostic studies were found in comparison to prognostic ones. Perhaps this is due to the fact that the early detection of malignant tumors is a more relevant need in clinical practice, but also, prognostic studies, especially the prospective ones, required a longer time of patient follow-up, which implicates in more costs and work demand.

The majority of studies were prospective. The bias that retrospective information provides enables the preference for a prospective study design, since: only larger tumors grant sufficient tissue for storage; and there is less control of the storage conditions of both tissue and plasma, leading to irregular data (Duffy, Crown, 2014).

Other uses for ccfDNA CRC management were not discussed in this review. Particularly. the use of ccfDNA for treatment follow-up (popularly known as liquid biopsy) has an important clinical utility since there are major mutations related to treatment response. For instance, the presence of $K R A S$ mutations indicates low 
response to treatment with antiEGFR drugs (cetuximabe, panitumumabe) and these mutations may occur at any time of disease progression. Analyzing this mutation in tumor tissue is a necessity but also an inconvenience. For that reason, the detection of a $K R A S$ mutation in ccfDNA is a way out of an invasive procedure, enabling a closer followup with blood exams in tighter windows. Unfortunately this was not comprised among the objectives of this review to avoid an over extensive research.

\section{ccfDNA in CRC diagnosis}

Studies based on diagnostic molecular biomarkers for CRC $(n=17)$ can be divided into main groups of biomarkers: ccfDNA quantification, metDNA (commonly methylated genes in CRC) and ccfDNA integrity (ccfDNA fragmentation).

The choice of a biological sample in most studies $(\mathrm{n}=21)$ was plasma, whereas only 5 studies used serum. Such a choice might be explained by the differences in the processing of plasma and serum samples. To obtain serum, a clotting process of the whole blood is necessary before separating serum from the blood cells. The lysis of white blood cells can occur during the clotting process, leading to a higher quantity of ccfDNA contaminated with genomic DNA (El Messaoudi et al., 2013). Therefore, it is not ideal to use serum as a biological sample when analyzing the total amount of ccfDNA. As expected, studies that used serum had higher ccfDNA quantification values in both control and CRC patients.

Basic requirements to validate proper diagnostic biomarkers are sensitivity and specificity, and accuracy obtained through a robust ROC curve (used to set cut-off points) (Duffy, Crown, 2014).

\section{ccfDNA quantification biomarkers}

As for analytical methods, quantitative PCR (qPCR) was the method used to measure ccfDNA levels in 4 out of 9 CRC studies. The remaining studies quantified ccfDNA by UV spectrophotometry $(n=1)$, fluorimetry $(n=2)$, and color-based (DipStick) $(\mathrm{n}=1)$ methods (Table I).

All studies that measured ccfDNA levels as a biomarker for CRC diagnosis $(n=9)$ had a prospective design (Table II). These studies selected 20-223 CRC patients and 20-99 healthy subjects. Tumor staging varied from primary $(\mathrm{n}=4)$ to stage IV and metastatic $(\mathrm{n}=5)$.

Most of the studies ( $n=7)$ used plasma whereas only two studies used serum to extract ccfDNA. DNA was extracted using Qiagen $(\mathrm{n}=6)$ or Applied Biosystems $(n=1)$ technologies, which are silica-based nucleic acid purification kits for different types of biological samples.
One study used DNA-Technology to isolate DNA by a universal precipitation-based method, and one study analyzed ccfDNA directly from serum samples (Table II).

Overall, ccfDNA quantification ranged from 25-868 $\mathrm{ng} / \mathrm{ml}$. The two studies that used serum had higher ccfDNA quantification values in CRC patients: $868(22$ - 3922) $\mathrm{ng} / \mathrm{ml}$ (median) for stage IV CRC patients and $798 \pm 409$ $\mathrm{ng} / \mathrm{mL}$ (mean) for primary CRC patients (Table II). In contrast, the higher value obtained with plasma samples was 437 (IQR 191-750) ng/ml (median) with primary and recurrent CRC patients (Table II).

The majority of studies $(n=6)$ was able to demonstrate a significant difference in ccfDNA quantification between cancer patients and healthy subjects (Table II).

Based on qPCR methods for ccfDNA quantification, two studies found low ccfDNA levels. In CRC patients, the values were $26 \mathrm{ng} / \mathrm{ml}$ (Moulière et al., 2014) and 29.45 $\pm 12.24 \mathrm{ng} / \mathrm{ml}$ (Kondratov et al., 2014) while two others (Frattini et al., 2008; Frattini et al., 2006) reported high ccfDNA concentrations (437 (IQR 191-750) ng/ml and 495.7 (100-1750) ng/ml, respectively (Table II).

One study used different values for quantification (alleles $/ \mathrm{ml}$ ) and therefore had different quantitative results 17900 (800 - 4618400) alleles/ml for CRC patients. Still there was a significant difference between cancer patients and controls in this study $(\mathrm{p}<0.0001)$ (Table II).

Three out of 9 studies presented data on sensitivity and specificity. The ROC curve analysis with AUC values ranged from 0.84-0.94 (Table II). As for cut-off values, Czeiger et al. (2011) used a cut-off of $841 \mathrm{ng} / \mathrm{ml}$ leading to a sensitivity and specificity of $42 \%$ and $94 \%$, respectively, and Kondratov et al. (2014) had $17.7 \mathrm{ng} / \mathrm{ml}$ as cut-off value leading to the detection of 8 out of $20 \mathrm{CRC}$ cases.

Studies have demonstrated that ccfDNA quantification differs among tumor stages and metastatic CRC has the highest values (Cassinotti et al., 2013; Lin et al., 2014). Therefore, metastatic CRC represents a bias in diagnostic parameters based on ccfDNA quantification, since metastatic CRC values are more likely to differ from healthy subjects and the main clinical need is early diagnosis. In this review, 4 out of 8 studies on the CRC diagnosis limited their population to only metastatic CRC and one of them had the highest AUC value observed in this review of 0.949 (Table II). In contrast, Czeiger et al. (2011) obtained a ROC curve AUC value of 0.84 with primary CRC patients, conceptually a more reliable and clinically useful result.

Among the biomarkers analyzed in this review, ccfDNA quantification had consistent results, both for the diagnosis and prognosis analysis. Moreover quantitative PCR as the analytical method seems to be adequate for 
TABLE I - Analytical Methods for the quantification of ccfDNA and other biomarkers in the CRC diagnosis

\begin{tabular}{|c|c|c|c|}
\hline Type of biomarker & Biomarker & Analytical method & Reference \\
\hline \multirow[t]{4}{*}{ ccfDNA Quantification } & $\operatorname{ccfDNA}(\mathrm{ng} / \mathrm{mL})$ & qPCR & $\begin{array}{c}\text { Mouliére et al., 2014; Kondratov et } \\
\text { al., } 2014 .\end{array}$ \\
\hline & & UV spectrophotometry & Schwarzenbach et al., 2008 \\
\hline & & DNA DipStick Kit & $\begin{array}{l}\text { Frattini et al., 2008, Frattini et al., } \\
2006\end{array}$ \\
\hline & ccfDNA (alleles/mL) & qPCR & Spindler et al., 2015 \\
\hline \multirow[t]{7}{*}{ MetDNA } & $\mathrm{mGATA5}$ & $\begin{array}{l}\text { Qiagen Epitect Plus DNA } \\
\text { bisulfite kit + MSP }\end{array}$ & Zhang et al., 2015 \\
\hline & $\mathrm{mFOXE1}$ & EpiTect Bisulphite Kit + MSP & Melotte et al., 2015 \\
\hline & mSYNE1 & EpiTect Bisulphite Kit + MSP & Melotte et al., 2015 \\
\hline & $\mathrm{mPPP} 1 R 3 C$ & $\begin{array}{c}\text { Zymo EZ DNA Methylation Kit } \\
+ \text { MSP }\end{array}$ & Takane et al., 2014 \\
\hline & $\mathrm{m} E F H D 1$ & $\begin{array}{c}\text { Zymo EZ DNA Methylation Kit } \\
+ \text { MSP }\end{array}$ & Takane et al., 2014 \\
\hline & $\mathrm{mSEPT9}$ & Epi proColon Assay & Church et al., 2014 \\
\hline & & $\begin{array}{c}\text { Bisulfite conversion }+ \text { Real time } \\
\text { PCR }\end{array}$ & deVos et al., 2009 \\
\hline \multirow{2}{*}{ ccfDNA Integrity } & & qPCR & Yoruker et al., 2015 \\
\hline & $A C T B^{384} / A C T B^{106}$ & qPCR & Yoruker et al., 2015 \\
\hline
\end{tabular}

ccfDNA: circulating cell free DNA; metDNA: methylated CRC genes; qPCR: quantitative polymerase chain reaction; MSP: methylation-specific polymerase chain reaction; $A L U$ : Arthrobacter luteus; $A C T B$ : beta-actin gene.

both purposes. However, ccfDNA quantification is yet to be proven clinically specific, since elevated levels of ccfDNA can be observed in other diseases (Wang, $\mathrm{Chen}, \mathrm{Wu}, 2014)$. This is not adequate for a diagnostic biomarker. Clinically, a suspicion of CRC has to be already in place so that this biomarker can be applied and this application does not solve the issue of early detection for CRC.

Perhaps an application for this biomarker in clinical practice would be the implementation of ccfDNA quantification in routine blood exams. That way, when altered, ccfDNA levels could indicate an early malignancy appearance or other diseases (Wang, Chen, Wu, 2014). Early disease investigation and an early treatment and management of the disease would then take place.

After these considerations, an important need to establish the optimal DNA extraction method for ccfDNA quantification analysis remains, so that afterwards, clinical validation of the whole procedure could take place.

\section{Integrity biomarkers}

Two CRC studies analyzed DNA integrity using the $A L U$ repeats and $A C T B$ loci as targets. $A L U$ repeats are the most abundant sequences in the human genome. 
TABLE II - Clinical studies that evaluated the ccfDNA quantification as biomarker for the CRC diagnosis

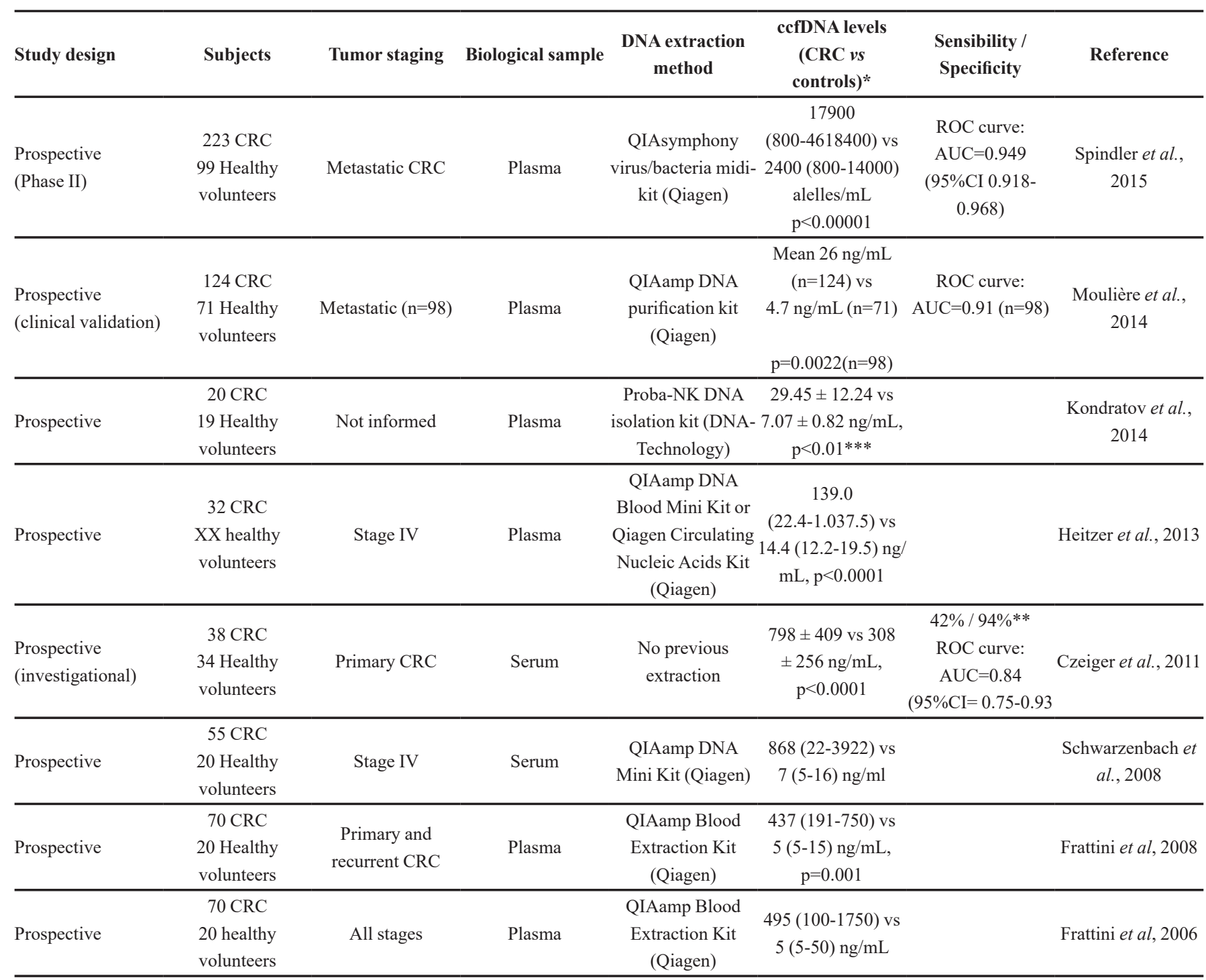

CRC: colorectal cancer; ccfDNA: circulating cell-free DNA; ROC: Receiver operating characteristic; AUC: area under the curve; $95 \%$ CI: $95 \%$ confidence interval; IQR: interquartil range ; * The results are shown as mean \pm SD or median $(\mathrm{IQR}) . * *$ Cutoff value: $841 \mathrm{ng} / \mathrm{mL} . . * * *$ Upper cut-off value $17.7 \mathrm{ng} / \mathrm{ml}$ detected $8 / 20 \mathrm{CRC}$

$A L U$ sequences are short interspersed elements (SINEs), typically 300 nucleotides, which account for more than $10 \%$ of the genome.

In the $A L U$ real-time qPCR, a consensus sequence with abundant genomic $A L U$ repeats was amplified and quantified. (Umetani et al., 2006). ACTB is a region of variable size located in the beta-actin $(A C T B)$ gene, which is a single copy gene. The analytical method in both studies was qPCR (Table I).

ccfDNA has DNA fragments that vary in length. The integrity of ccfDNA has been widely studied and experimental studies with human CRC xenografts have revealed a high fragmentation (e.g. reduced integrity) of ccfDNA. However, with the patient's samples, the results are inconsistent. Clinical studies on this subject have found increased DNA integrity but others have found a reduced DNA integrity (Yörüker et al., 2015).

Two studies (Hao et al., 2014; Yörüker et al., 2015 ) evaluated integrity biomarkers. Both studies had a prospective design, used serum as a biological sample and both included all stages of CRC (Table III). The number of CRC patients was 205 for Hao et al. (2014) and 72 for Yörüker et al. (2015). The extraction methods were different from those used in the studies of ccfDNA quantification biomarkers.

Specific sizes of the $A L U$ (115 and 247) and $A C T B$ (106 and 384) loci were amplified by qPCR. The integrity index was calculated based on the ratio of DNA 
quantification between the long and the short fragments $\left(A L U^{247} / A L U^{115}\right.$ or $\left.A C T B^{384} / A C T B^{106}\right)$.

Hao et al. (2014) was able to provide significant results for a diagnostic biomarker, with high accuracy (AUC ROC curve 0.89) and good sensitivity (69.2\%) and specificity (99.1\%) (Table III) while Yörüker et al. (2015) achieved a borderline significance for the difference between patients and controls in both $A L U^{247} / A L U^{115}$ and $A C T B^{384} / A C T B^{106}$ integrity indexes. (Table III).

Serum processing also affects the other biomarkers comprised in this review since a contaminated sample with genomic DNA leads to an imprecise quantity of ccfDNA which can diminish the sensibility of the gene mutation detection methods. In addition, the genomic DNA is less fragmented (higher integrity) than circulating DNA. This genomic DNA contamination can explain the divergent results encountered in both studies that evaluated ccfDNA integrity in this review. Hao et al. (2014) is based on the hypothesis that ccfDNA released from apoptotic cells is uniformly truncated into 185-200 bp fragments and ccfDNA released from necrotic tumor cells varies in length, which may lead to an elevation of DNA with long fragments in serum or plasma (Hao et al., 2014). In contrast, Yörüker et al. (2015) was based on the information of experimental studies with human CRC xenografts that have revealed a high fragmentation (e.g. reduced integrity) of ccfDNA. Therefore, the genomic DNA contamination can enhance the results for Hao et al. (2014) and worsen the results for Yörüker et al. (2015). It is important to add that Hao et al. (2014) did a remarkable analysis for this diagnostic biomarker with all the parameters and presented good results, but still the choice of serum as a biological sample must matter.

\section{Methylated biomarkers}

The analytical method was different for each study that evaluated metDNA(Table I). Four used a commercial bisulfite conversion kit prior to the methylation specific PCR (MSP), one used a specific commercial kit that

TABLE III - Clinical studies that evaluated the ccfDNA integrity and fragmentation as a biomarker for the CRC diagnosis

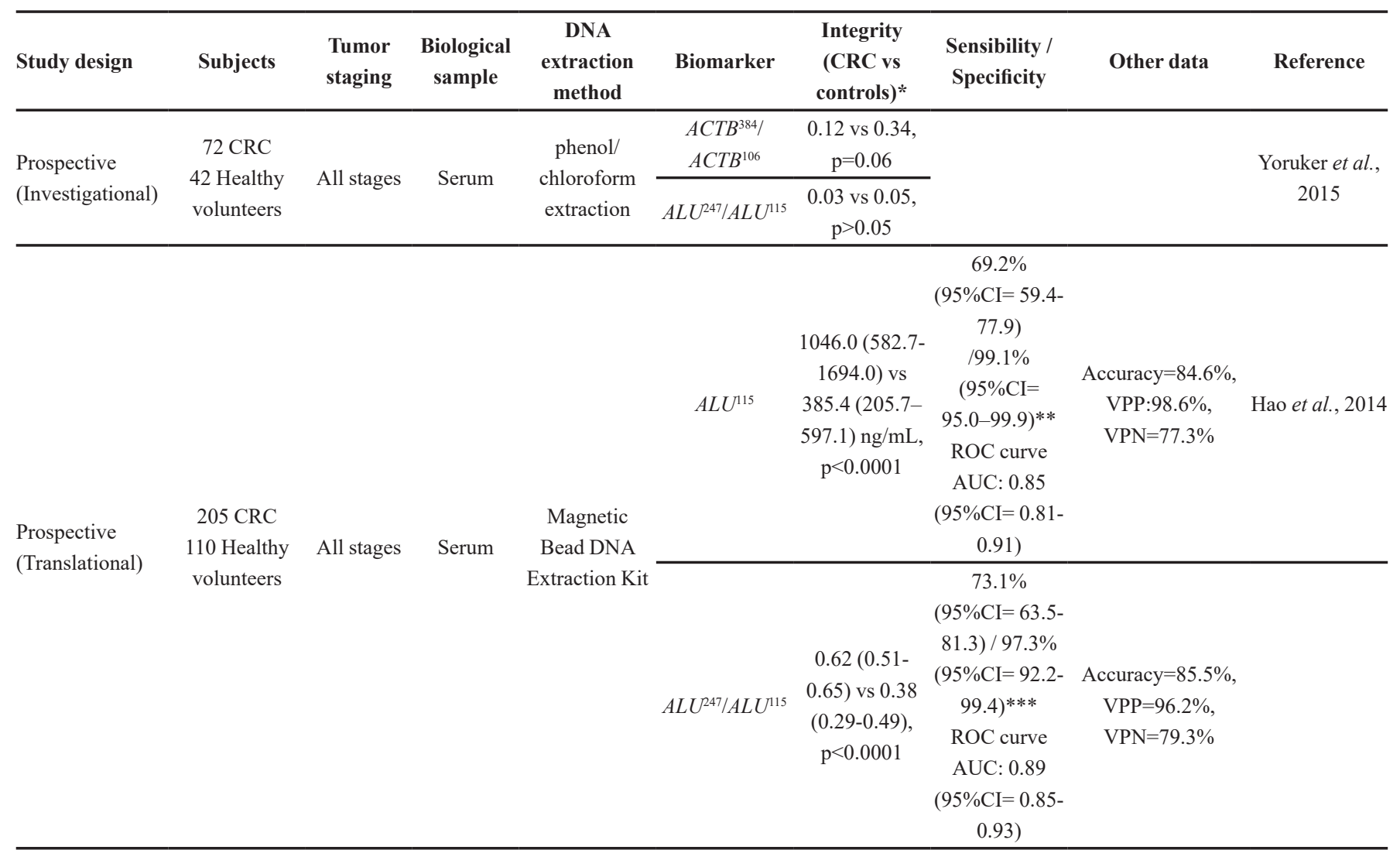

CRC: colorectal cancer; $A C T B$ : beta-actin gene; $A L U$ : 7 short interspersed elements (SINEs) in the genome; $A L U^{247} / A L U^{115}$ and $A C T B^{384} / A C T B^{106}$ : integrity indexes where the quantification of one size is divided by the quantification of the other size; $95 \% \mathrm{CI}$ : $95 \%$ confidence interval; NPV: negative predictive value; PPV: positive predictive value; ROC: receiver operating characteristic; AUC: area under the curve.* Results are shown as mean \pm SD or median $(\mathrm{IQR}) . * *$ cut-off value $=694$ ng/ $\mathrm{mL} * * *$ cutoff value $=0.52 ;$ AUC: area under the curve. 
includes PCR and one applied real time PCR for analysis after the ccfDNA bisulfite conversion (Table I).

All 6 studies had a prospective design. Of all of them, two were case-control studies. These studies selected 53-120 CRC patients and 47-1457 healthy subjects. There was no limit to tumor staging in 4 studies, one had only carcinomas and the other had only asymptomatic CRC. All of the studies used plasma as the biological sample. A variety of commercial DNA extraction kits was found among the extraction method of the studies as seen above for ccfDNA quantification studies (Table I). Ten different methylated genes were assessed in this review (mGATA5, $\mathrm{mSFRP} 2, \mathrm{mITGA4}$, $\mathrm{m} F O X E 1, \mathrm{~m} S Y N E 1, \mathrm{~m} P P P 1 R 3 C, \mathrm{~m} E F H D 1, \mathrm{mSEPT9}$, $\mathrm{m} B C A T 1$ and $\mathrm{m} I K Z F 1$ ) (Table IV).

The studies presented their results as either positivity or methylated frequency. In concept, both results presented the percentage of subjects positive for gene methylation in the study population and further on, will be referred to solely as methylation frequency. The methylation frequency for CRC patients ranged from $36.8 \%$ to $81 \%$ and for controls from $3.5 \%$ to $19 \%$. Three studies, comprising seven different genes, presented a significant difference between CRC and control groups (Table IV). Melotte et al. (2015) results are the combined analyses of two methylated genes mFOXE1 and mSYNE1.

In total, the 6 studies provided 12 results regarding sensitivity and specificity (Table IV). Only Pedersen et al. (2015) provided a ROC curve analysis with AUC values of $0.807,0.8135$ and 0.8469 for $\mathrm{m} B C A T 1, \mathrm{~m} I K Z F 1$ and $\mathrm{m} B C A T 1$ or $\mathrm{m} I K Z F 1$ methylated biomarkers, respectively. The remaining sensitivity values ranged from $42.9 \%$ to $72 \%$ and specificity values ranged from $78 \%$ to $95 \%$.

Regarding the methylated biomarkers, the results for metDNA were less significant than the ones found for quantitative biomarkers in the CRC diagnosis, since a significant difference between CRC and control groups was achieved in 3 out of 6 studies for metDNA and 6 out of 9 studies for ccfDNA quantification. Also, the analysis of methylated genes presents a disadvantage for clinical practice, because it requires an additional step in the sample processing, the bisulfite conversion, thus it is one more variable to be validated in terms of repeatability and reproducibility implicating also in greater costs.

\section{ccfDNA in CRC prognosis}

Eleven studies assessed the CRC prognostic value of ccfDNA-based biomarkers, which are grouped in two categories: (i) ccfDNA quantification, and (ii) detection of gene mutations.
As shown in Table $\mathrm{V}$, seven studies measured ccfDNA levels as the prognosis biomarker, while eight studies detected mutations in CRC-related oncogenes (KRAS, BRAF and PIK3CA) and the tumor suppressor gene TP53. In clinical practice, the detection of mutations in these genes is associated with a worse prognosis.

\section{Analytical methods}

ccfDNA quantification was measured by three different PCR-based methods in five studies and by UV spectrophotometry in two studies.

Gene mutations were detected in ccfDNA using five different technologies: BEAMing (2 studies) ARMS-PCR (2 studies), PNA-PCR (1 study), DNA sequencing (1 study), and PCR-TGGE (1 study).

On the other hand, the majority $(n=7)$ of studies that evaluated prognostic biomarkers limited their population to only metastatic $\mathrm{CRC}$, which can be explained by the clinical trajectory of the CRC treatment (common surgical removal in colonoscopy for primary $\mathrm{CRC}$ ) and the timing in disease that prognostic biomarkers can be clinically useful (Duffy, Crown, 2014).

\section{Clinical studies characteristics}

Two retrospective and nine prospective studies evaluated ccfDNA levels and gene mutations for the CRC prognosis. The sample population in these studies ranged from 25-503 CRC patients mainly in the metastatic stage $(n=7)$ (Table VI). Only one in eleven studies used serum as a biological sample.

The DNA extraction method analysis showed 10 different types of methods. Interestingly, they were similar to the methods seen in studies for CRC diagnosis (Table VI).

Considered prognostic parameters were progression free survival (PFS) and overall survival (OS). A few results were presented as Hazard Ratios (HR), which is the ratio between hazard rates of two conditions of an explanatory variable. Two different approaches for survival analysis with HR are present in this review. One approach represents a drug study where the treated population may die at half the rate per unit time as the control population. The hazard ratio would be 0.5 , indicating lower hazard of death from the treatment. Whereas in another approach, the population bearing gene mutation may die two times more frequently per unit time than the wild type population, giving a hazard ratio of 2 .

\section{Gene mutations biomarkers for CRC prognosis}

Eight studies investigated the mutations as biomarker for CRC prognosis using OS and/or PFS approaches and 
TABLE IV - Clinical studies that evaluated the methylated biomarkers in the ccfDNA for the CRC diagnosis

\begin{tabular}{|c|c|c|c|c|c|c|c|c|c|}
\hline Study design & Subjects & Tumor staging & $\begin{array}{l}\text { Biological } \\
\text { sample }\end{array}$ & $\begin{array}{l}\text { DNA extraction } \\
\text { method }\end{array}$ & Biomarker & $\begin{array}{c}\text { metDNA } * * * * * \\
(\text { CRC vs } \\
\text { controls) }\end{array}$ & Sensibility / Specificity & Observations & Reference \\
\hline \multirow{3}{*}{$\begin{array}{l}\text { Prospective } \\
\text { (Translational) }\end{array}$} & \multirow{3}{*}{$\begin{array}{l}57 \text { CRC } \\
47 \text { Healthy } \\
\text { volunteers }\end{array}$} & \multirow{3}{*}{ Carcino-mas } & \multirow{3}{*}{ Plasma } & \multirow{3}{*}{$\begin{array}{l}\text { QIAamp DNA } \\
\text { Blood mini kit }\end{array}$} & $\mathrm{m} G A T A 5$ & $\begin{array}{c}\text { Met: } 63.4 \% \text { vs } \\
21.28 \% \mathrm{p}<0.01 \\
\end{array}$ & \multirow{2}{*}{$42.9 \%$ / $91.5 \%$} & \multirow{2}{*}{$\begin{array}{c}\mathrm{OR}=8.06 \\
(95 \% \mathrm{CI}=2.54- \\
25.5), \mathrm{p}<0.01\end{array}$} & \multirow{3}{*}{$\begin{array}{c}\text { Zhang X et } \\
\text { al, } 2015\end{array}$} \\
\hline & & & & & $\mathrm{m} S F R P 2$ & $\begin{array}{l}\text { Met: } 54.4 \% \text { vs } \\
27.7 \%, p<0.01\end{array}$ & & & \\
\hline & & & & & $\mathrm{m} I T G A 4$ & $\begin{array}{c}\text { Met: } 36.8 \% \text { vs } \\
19.2 \%, p=0.048\end{array}$ & & & \\
\hline \multirow{2}{*}{ Prospective } & \multirow{2}{*}{$\begin{array}{c}66 \text { CRC } \\
240 \\
\text { asymptomatic } \\
\text { without } \\
\text { detection }\end{array}$} & \multirow{2}{*}{ All stages } & \multirow{2}{*}{ Plasma } & \multirow{2}{*}{$\begin{array}{l}\text { QIAamp } \\
\text { Circulating } \\
\text { Nucleic Acid } \\
\text { Test Kit }\end{array}$} & $\mathrm{m} F O X E 1$ & \multirow{2}{*}{$\begin{array}{c}\text { Combined } \\
\text { Positivity } 38 / 66 \\
(57 \%) \text { vs } 21 / 240 \\
(8.7 \%)\end{array}$} & \multirow{2}{*}{$\begin{array}{l}\text { Combined analysis 58\% } \\
(95 \% \mathrm{CI}=46-70 \%) / 91 \% \\
(95 \% \mathrm{CI}=80-100 \%) *\end{array}$} & $\begin{array}{c}\text { ROC curve } \\
\text { AUC }=0.70 \\
(95 \% \mathrm{CI}=0.69- \\
0.73)^{* *} \\
\end{array}$ & \multirow{2}{*}{$-\begin{array}{c}\text { Melotte V et } \\
a l, 2015\end{array}$} \\
\hline & & & & & $\mathrm{m} S Y N E 1$ & & & $\begin{array}{c}\text { ROC curve } \\
\text { AUC }=0.72 \\
(95 \% \mathrm{CI}=0.68- \\
0.75) * *\end{array}$ & \\
\hline \multirow[t]{2}{*}{$\begin{array}{l}\text { Prospective } \\
\text { (Case-control) }\end{array}$} & \multirow[t]{2}{*}{$\begin{array}{l}74 \text { CRC } \\
144 \text { Healthy } \\
\text { volunteers }\end{array}$} & \multirow[t]{2}{*}{ All stages } & \multirow[t]{2}{*}{ Plasma } & \multirow[t]{2}{*}{$\begin{array}{c}\text { QIAamp } \\
\text { Circulating } \\
\text { Nucleic Acid Kit }\end{array}$} & $\mathrm{m} I K Z F 1$ & $\begin{array}{c}\text { Positivity: } 68 \% \\
\text { (95\% } \mathrm{CI}=57- \\
78) \text { vs } 4.9 \% \\
(95 \% \mathrm{CI}=1.3- \\
8.4), \mathrm{p}<0.0001 \\
\end{array}$ & $\begin{array}{c}67.6(95 \% \mathrm{CI}=55.7-78.0) / \\
95.1(95 \% \mathrm{CI}=90.2-98.0)^{* * *} \\
\text { ROC curve AUC } 0.8135 \\
(95 \% \text { CI } 0.7448-0.8822)\end{array}$ & & \multirow[t]{2}{*}{$\begin{array}{c}\text { Pedersen SK } \\
\text { et al, } 2015\end{array}$} \\
\hline & & & & & $\begin{array}{c}\mathrm{m} B C A T 1 \text { or } \\
\mathrm{m} I K Z F 1\end{array}$ & & $\begin{array}{c}77.0(95 \% \mathrm{CI}=65.8-86.0) / \\
92.4(95 \% \mathrm{CI}=86.7-96.4)^{* * *} \\
\text { ROC curve AUC } 0.8469 \\
(95 \% \text { CI } 0.7848-0.9091)\end{array}$ & & \\
\hline $\begin{array}{l}\text { Prospective } \\
\text { (Investigational) }\end{array}$ & $\begin{array}{l}120 \text { CRC } \\
96 \text { Healthy } \\
\text { volunteers }\end{array}$ & All stages & Plasma & $\begin{array}{c}\text { QIAamp } \\
\text { Circulating } \\
\text { Nucleic Acid Kit }\end{array}$ & $\mathrm{m} P P P 1 R 3 C$ & $\begin{array}{c}\text { Met: } 81 \% \text { vs } \\
19 \%, p<0,0001\end{array}$ & $81 \% / 81 \%$ & $\begin{array}{c}\text { Combined } \\
\text { analysis: } \\
\text { sensitivity } 53 \% \\
\text { and specificity } \\
96 \%\end{array}$ & $\begin{array}{c}\text { Takane K et } \\
a l, 2014\end{array}$ \\
\hline \multirow{3}{*}{$\begin{array}{l}\text { Prospective } \\
\text { (Case-control) }\end{array}$} & \multirow{3}{*}{$\begin{array}{c}90 \text { CRC } \\
155 \text { Healthy } \\
\text { volunteers }\end{array}$} & \multirow{3}{*}{ All stages } & \multirow{3}{*}{ Plasma } & \multirow{3}{*}{$\begin{array}{c}\text { modified } \\
\text { Chemagic viral } \\
\text { DNA/RNA kit }\end{array}$} & \multirow{3}{*}{$\mathrm{mSEPT9}$} & $\begin{array}{c}\text { High sensitivity } \\
\text { analysis: } 65 / 90 \\
(72 \%) \text { vs } 22 / 155 \\
(14.1 \%)^{* * * *} \\
\end{array}$ & $72 \% / 86 \%$ & & \multirow{3}{*}{$\begin{array}{c}\text { deVos T et al, } \\
2009\end{array}$} \\
\hline & & & & & & $\begin{array}{l}\text { High specificity } \\
\text { analysis : } 50 / 90 \\
(55 \%) \text { vs } 7 / 155 \\
(4.5 \%)^{* * * *} \\
\end{array}$ & $55 \% / 95 \%$ & & \\
\hline & & & & & & $\begin{array}{c}\text { Conditional } \\
\text { qualitative } \\
\text { analysis: } 62 / 90 \\
(68 \%) \text { vs } 17 / 155 \\
(11 \%)^{* * * *}\end{array}$ & $69 \% / 89 \%$ & & \\
\hline
\end{tabular}

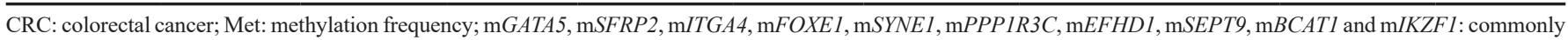
methylated genes in CRC; 95\% CI: 95\% confidence interval; NPV: negative predictive value; PPV: positive predictive value; ROC: receiver operating characteristic; AUC: area under the curve. * cutoff = zero; ** ROC curve AUC results from the training set: 154 CRC and 444 controls; *** Threshold cut: any positive replicate out of three replicates;**** for each sample PCR was made 3 times. In the high sensitivity analysis sample were considered positive if at least one of the PCR reactions were positive. For the high specificity analysis samples were positive if at least 2 out of 3 were positive and the conditional qualitative analysis is a conditional algorithm further explained in the study deVos T, et al 2009; ***** See text for results details. The ROC curve analysis was found in 2 studies and the AUC values ranged from $0.70-0.84$. The only methylated gene analyzed in more than one study was SEPT9 though with different analytical methods (Table IV). Based on sensitivity and specificity analysis, with the aid of ROC curve analysis, the most promising methylated biomarker in this review was the detection of $\mathrm{m} B C A T 1$ or $\mathrm{m} I K Z F 1$ (Pedersen SK, 2015). Values for sensitivity and specificity were $77.0(95 \% \mathrm{CI} 65.8-86.0)$ and $92.4(95 \% \mathrm{CI} 86.7-96.4)$ respectively, and the AUC value was $0.8469(95 \%$ CI $0.7848-0.9091)$ for the ROC curve analysis. 
TABLE V - Analytical methods for the quantification of ccfDNA and other biomarkers in the CRC prognosis

\begin{tabular}{|c|c|c|}
\hline Biomarker & Analytical method & Reference \\
\hline \multirow[t]{4}{*}{ ccfDNA quantification } & LINE-1 qRT-PCR & Tabernero et al., 2015; Wong et al., 2015. \\
\hline & $\mathrm{qPCR}$ & Spindler et al., 2015; Spindler et al., 2012. \\
\hline & Rt PCR & Lin et al., 2014. \\
\hline & Spectrophotometry & $\begin{array}{l}\text { Schwarzenbach et al., 2008; Guadalajara et al., } \\
2008 .\end{array}$ \\
\hline \multirow[t]{6}{*}{$K R A S$} & BEAMing & Tabernero et al., 2015; Wong et al., 2015. \\
\hline & ARMS-qPCR & Spindler et al., 2015; Spindler et al., 2013. \\
\hline & PNA-PCR & Xu et al., 2014. \\
\hline & DxS kit & Spindler et al., 2012. \\
\hline & Direct automatic sequencing & Bazan et al., 2006. \\
\hline & Temperature gradient gel electrophoresis (TGGE) & Lindforss et al., 2005. \\
\hline PIK3CA & BEAMing & Tabernero et al., 2015; Wong et al., 2015. \\
\hline \multirow[t]{2}{*}{$B R A F$} & BEAMing & Tabernero et al., 2015; Wong et al., 2015. \\
\hline & ARMS-qPCR & Spindler et al., 2013. \\
\hline TP53 & Direct automatic sequencing & Bazan et al., 2006. \\
\hline
\end{tabular}

ccfDNA: circuating cell-free DNA; Rt: real-time; qPCR: quantitative polymerase chain reaction.

TABLE VI - Characteristics of the clinical studies that evaluated gene mutation present in the ccfDNA and the ccfDNA quantification for the CRC prognosis

\begin{tabular}{|c|c|c|c|c|c|}
\hline Study design & Subjects & Tumor staging & Biological sample & DNA extraction method & Reference \\
\hline Retrospective & 503 & Metastatic CRC & Plasma & $\begin{array}{l}\text { QIAamp DNA purification } \\
\text { kit }\end{array}$ & $\begin{array}{l}\text { Tabernero et al., } \\
2015\end{array}$ \\
\hline Prospective (Open) & 33 & $\begin{array}{c}\text { Refractory } \\
\text { metastatic CRC }\end{array}$ & Plasma & $\begin{array}{l}\text { QIAamp DNA purification } \\
\text { kit }\end{array}$ & Wong et al., 2015 \\
\hline $\begin{array}{l}\text { Prospective } \\
\text { (Phase II) }\end{array}$ & 211 & Metastatic CRC & Plasma & $\begin{array}{c}\text { QIAsymphony virus/ } \\
\text { bacteria midi-kit }\end{array}$ & Spindler et al., 2015 \\
\hline Retrospective & 242 & Metastatic CRC & Plasma & $\begin{array}{c}\text { NucleoSpinß Plasma, } \\
\text { N.740900 }\end{array}$ & Xu et al., 2014 \\
\hline $\begin{array}{l}\text { Prospective } \\
\text { (Translational) }\end{array}$ & 133 & All stages & Plasma & $\begin{array}{l}\text { QIAamp DNA Tissue Kit } \\
\text { and Minelute Virus Kit }\end{array}$ & Lin et al., 2014 \\
\hline Prospective (Cohort) & 95 & Metastatic CRC & Plasma & $\begin{array}{l}\text { QIAsymphony virus/ } \\
\text { bacteria midi-kit on a } \\
\text { QIAsymphony robot }\end{array}$ & Spindler et al., 2013 \\
\hline $\begin{array}{l}\text { Prospective } \\
\text { Investigational }\end{array}$ & 108 & Metastatic CRC & Plasma & $\begin{array}{l}\text { Automated QIAsymphony } \\
\text { virus/bacteria midi-kit }\end{array}$ & Spindler et al., 2012 \\
\hline Prospective Clinical & 55 & Stage IV & Serum & QIAamp DNA Mini Kit & $\begin{array}{c}\text { Schwarzenbach et } \\
\text { al., } 2008\end{array}$ \\
\hline Prospective & 73 & All stages & Plasma & QIAamp $^{\mathrm{TM}}$ kit & $\begin{array}{c}\text { Guadalajara et al., } \\
2008\end{array}$ \\
\hline Prospective & 50 & Primary CRC & Plasma & Ultrasense Virus Kit & Bazan et al., 2006 \\
\hline Prospective & 25 & Stages I, II and III & Plasma & Qiamp DNA Blood kit & Lindforss et al., 2005 \\
\hline
\end{tabular}

CRC: colorectal cancer. 
seven studies assessed the general accordance in mutation detection between plasma and tissue (Table VII). All gene mutation analyses presented were made in ccfDNA.

\section{KRAS}

Tabernero et al. (2015), a drug study, used the hazard ratio (HR) between placebo and treatment groups for both OS and PFS showing a lower death rate in both mutated and wild type groups. However, the interaction $p$ value between mutant and wild type groups was not significant for either OS or PFS (Table VII).

Spindler et al. (2013) showed a significant difference between mutated and wild type groups both in OS and PFS and the HR was 2.26 for OS and 1.69 for PFS showing a bad prognosis in both analyses. Xu et al. (2014) analyzed only the OS and showed a significant difference between groups. Wong et al. (2015) analyzed only PFS and showed a significant difference between groups.

Three studies presented other results that did not fall into the OS and PFS analysis. Bazan et al. (2006) had a positive relationship between $K R A S$ mutation and quicker disease relapse. On the other hand, Lindforss et al. (2015) did not correlate $K R A S$ mutation with disease relapse. Spindler et al. (2012) correlated KRAS with ccfDNA quantification, but the difference between mutation and wild type groups was not significant.

Overall concordance of KRAS mutation detection in plasma and tissue samples was evaluated in 8 studies. The values ranged from $56-85 \%$ (Table VII).

\section{PIK3CA}

One study (Tabernero et al., 2015) evaluated

TABLE VII - Results for the detection of mutations in the ccfDNA for the CRC prognosis

\begin{tabular}{|c|c|c|c|c|c|c|c|c|}
\hline \multirow{2}{*}{ Biomarker } & \multicolumn{3}{|c|}{ Overall survival } & \multicolumn{3}{|c|}{ Progression free survival } & \multirow{2}{*}{$\begin{array}{c}\begin{array}{c}\text { Mutation } \\
\text { detection }\end{array} \\
\text { accordance }\end{array}$} & \multirow{2}{*}{ Reference } \\
\hline & Mutation & Wild type & $p$ value and $H R$ & Mutant & Wild type & $p$ value and $H R$ & & \\
\hline \multirow{13}{*}{$K R A S$} & & & & (95\%CI & $(95 \%$ CI & & & \\
\hline & & & & $0.40-0.65)$ & $0.35-0.76)$ & & & \\
\hline & & & & 105 (95\%CI 58- & 217 & $p=0.04$ & - & Wong et al., 2015 \\
\hline & & & & & days & & & \\
\hline & & & & & & & $85 \%$ & Spindler et al., \\
\hline & & & & & & & & \\
\hline & Median 15.7 & Median 19.1 & $\mathrm{p}=0.009$ & & & & $177 / 242(73 \%)$ & Xu et al., 2014 \\
\hline & $(95 \%$ CI $13.0-18.4)$ & (95\%CI 16.8-21.4) & & & & & & \\
\hline & Median ccfDNA $K R$ & $A S$ wild type 19500 & (2000-4600000) vs $K$ & $K R A S$ mutant 25000 & $0(2600-610000)$ al & lleles $/ \mathrm{ml} \mathrm{p}>0.05$ & $90 \%$ & Spindler et al., \\
\hline & (not significant)* & & & & & & & 2012 \\
\hline & KRAS mutations prov & ved to be significantly & ly related to quicker & relapse $(\mathrm{P}<0.01)^{* *}$ & & & $18 / 50(36 \%)$ & Bazan et al., 2006 \\
\hline & The presence of $K R A$ & $4 S$ in tissue or plasma & a did not correlate wi & ith disease relapse. & Positivity $16 / 25(6$ & $64 \%)^{* *}$ & $9 / 16(56 \%)$ & Lindforss et al., \\
\hline & & & & & & & & 2005 \\
\hline \multirow[t]{3}{*}{ PIK3CA } & $\mathrm{HR}=0.84$ & $\mathrm{HR}=0.75$ & $\mathrm{P}=0.72$ & $\mathrm{HR}=0.54$ & $\mathrm{HR}=0.50$ & $\mathrm{p}=0.85$ & $88 \%$ & Tabernero et al., \\
\hline & $(95 \%$ CI $0.47-1.50)$ & (95\%CI 0.57-0.99) & & $(95 \% \mathrm{CI}$ & $(95 \% \mathrm{CI}$ & & & 2015 \\
\hline & & & & $0.32-0.89)$ & $0.40-0.63)$ & & & \\
\hline$B R A F$ & & & & & & & $97 \%$ & Tabernero et al., \\
\hline
\end{tabular}


PIK3CA mutation for CRC prognosis and there was no significant difference between mutant and wild type groups. The overall concordance between plasma and tissue in this study for PIK3CA gene was $88 \%$ (Table VII).

\section{$B R A F$}

One study (Spindler et al., 2013) had OS and PFS analysis for $B R A F$ mutation. This study showed a significant difference between groups $(\mathrm{p}<0.05)$ and HR values (0.34 IC 95\% 0.09-1.19 for OS and 0.29 IC 95\% $0.08-1.13$ for PFS) showed a lower death rate and a better prognosis for the wild type group but these results were not significant considering the confidence interval analysis. (Table VII). Overall concordance in gene mutation detection between plasma and tissue for $B R A F$ ranged from $97-100 \%$ (Table VII).

\section{TP53}

Unfortunately only a trend towards statistical significance $(\mathrm{P}=0.083)$ was observed for the TP53 mutations in one study (Table VII).

Regarding prognostic biomarkers, some studies justified the difference in gene mutation detection between plasma and tissue with the concept of tumor heterogeneity (Xu et al., 2014). Mutations present in the tumor may not be identified in the biopsy, since it is not always possible to extract and analyze the whole tumor mass, but they can appear in plasma analysis thanks to tumor-derived ccfDNA (Xu et al., 2014). Despite the small number of studies $(\mathrm{n}=2) B R A F$ seems to be the mutation in ccfDNA that better reflects tumor DNA content with $97 \%$ and $100 \%$ of overall accordance between plasma and tissue.

Regarding prognostic biomarkers, some studies justified the difference in gene mutation detection between plasma and tissue with the concept of tumor heterogeneity (Xu et al., 2014). Mutations present in the tumor may not be identified in the biopsy, since it is not always possible to extract and analyze the whole tumor mass, but they can appear in plasma analysis thanks to tumor-derived ccfDNA (Xu et al., 2014). Despite the small number of studies ( $\mathrm{n}=2) B R A F$ seems to be the mutation in ccfDNA that better reflects tumor DNA content with $97 \%$ and $100 \%$ of overall accordance between plasma and tissue.

\section{Results for ccfDNA quantification biomarkers}

To obtain the results for CRC prognosis using ccfDNA quantification biomarkers, studies divided their groups into high ccfDNA content and low ccfDNA content. The threshold for dividing the patients between groups was the median value in 3 studies, (Tabernero et al., 2015; Lin et al., 2014; Spindler et al., 2012; Spindler et al., 2015) used the upper normal limit value (median plus two standard deviations $=7100$ alleles $/ \mathrm{ml}$ ).

There were four studies with OS results and all of their findings showed that low ccfDNA content indicates better prognosis. Two of them presented quantitative values (Spindler et al., 2015; Spindler et al., 2012) measured in months and they both achieved statistically significant differences between groups.

The HR of 1.78 in Spindler et al. (2015) represented the risk for the high ccfDNA group, which indicates a worse prognosis for that group (Table VIII). The HR of 0.31 in Tabernero et al. (2015) represents the risk for the low ccfDNA group indicating a better prognosis for that group. Lin et al. (2014) analysis for OS analysis were based on the survival rate in a follow-up period of 5 years and there was a significant difference between high ccfDNA and low ccfDNA groups $(\mathrm{p}=0.001)$. In this study, the HR for the high ccfDNA group was 3.25 in the univariate analysis and 2.61 in the multivariate analysis.

Two studies showed results for the PFS analysis. Tabernero et al. (2015) HR of 0.62 indicates a better prognosis for the low ccfDNA groups. Spindler et al. (2012) gave the results in quantitative data and the differencebetween high and low groups was statistically significant (Table VIII).

Schwarzenbach et al. (2008) demonstrated that high ccfDNA content is correlated to a shorter survival $(\mathrm{p}=0.02)$ and Guadalajara et al. (2008) showed only a trend toward a worse prognosis for high ccfDNA content (Table VIII).

The validity of total ccfDNA quantification analysis as a biomarker may reside in prognosis. This review collected important results for this analysis where significant differences were found in OS and PFS analysis for patients with high and low ccfDNA content in plasma. In addition, the analytical technique qPCR and its derivatives seem to be a perfectly valid technique and has shown more relevant results in this review. Perhaps further studies on this subject can lead to the implementation of a new prognostic biomarker for CRC in clinical practice.

\section{CONCLUSION}

The lack of homogeneity in study designs and techniques is a challenge when comparing their results. It is difficult to choose a biomarker and analytical method to invest in for clinical validation. Nevertheless, few impressions lead the way for possible future research. The use of ccfDNA quantification in prognosis seems promising when analyzing the data obtained in this review. In addition to prognosis, ccfDNA quantification 
TABLE VIII - Results for the ccfDNA quantification biomarkers for the CRC prognosis

\begin{tabular}{|c|c|c|c|c|c|c|c|}
\hline \multicolumn{3}{|c|}{ Overall survival } & \multicolumn{3}{|c|}{ Progression free survival } & \multirow[t]{2}{*}{ Threshold } & \multirow[t]{2}{*}{ Reference } \\
\hline High ccfDNA & Low ccfDNA & p value and $H R$ & High ccfDNA & Low ccfDNA & p value and $H R$ & & \\
\hline & & $\begin{array}{c}\mathrm{HR}=0.31 \\
(95 \% \mathrm{CI} 0 \cdot 20-0 \cdot 47)\end{array}$ & & & $\begin{array}{c}\mathrm{HR}=0.62 \\
(95 \% \mathrm{CI} 0.45-0.86)\end{array}$ & Median & $\begin{array}{l}\text { Tabernero et al., } \\
2015\end{array}$ \\
\hline $\begin{array}{c}5.2 \text { months } \\
(95 \% \text { CI } 4.6-5.9)\end{array}$ & $\begin{array}{c}10.2 \text { months } \\
(95 \% \mathrm{CI} 8.3-11.7)\end{array}$ & $\begin{array}{l}\mathrm{HR}=1.78 \\
\mathrm{p}=0.0006\end{array}$ & & & & $\begin{array}{c}7100 \text { alleles/ } \\
\mathrm{ml})^{* * * *}\end{array}$ & $\begin{array}{l}\text { Spindler et al., } \\
2015\end{array}$ \\
\hline \multicolumn{7}{|c|}{ Kaplan-Meier analyses ccfDNA $>1000 \mathrm{ng} / \mathrm{mL}$ correlated with a shorter survival $\mathrm{P}=0.02 * * *$} & $\begin{array}{c}\text { Schwarzenbach et } \\
\text { al., } 2008\end{array}$ \\
\hline \multicolumn{7}{|c|}{ OS no significant correlation Mean $=108 \pm 156 \mathrm{ng} / \mu \mathrm{L}$. Cut-off $60 \mathrm{ng} / \mathrm{ml}$ showed a trend toward worse prognostics. (Kaplan } & $\begin{array}{c}\text { Guadalajara et al., } \\
2008\end{array}$ \\
\hline
\end{tabular}

ccfDNA: circulating cell-free DNA; 95\%CI: 95\% confidence interval; HR: hazard ratio;* univariate analysis ** multivariate analysis ***other data on prognosis; **** upper normal limit value.

can be used for treatment follow-up, prediction of recurrence or disease relapse and the sample collected for the prior purposes can be submitted to gene mutation detection, making ccfDNA a broad disease management biomarker. Results for the diagnostic value of ccfDNA were not so promising, however the combination of this biomarker with another existing biomarker should be considered: For example, Hao et al. (2014) studied the association of $A L U 115$ detection, DNA integrity with $A L U 247 / 115$ and CEA, which resulted in an accuracy of $91.59 \%$ showing how these biomarkers complement each other weakness. Still, it remains the need for a diagnostic method that can detect early occurrence of CRC is not. ccfDNA quantification as a diagnostic biomarker for $\mathrm{CRC}$ has promising results but it lacks clinical specificity since other diseases present a similar increase in ccfDNA content. However, the increasing research in the epigenomic field can lead the way to a clinically specific biomarker for CRC early diagnosis. As for an analytical method, qPCR and its derivatives seem to be a perfectly valid technique. The attempt to insert ccfDNA quantification into clinical practice may reside in prognosis using a qPCR technique. Further studies are needed to clinically validate this disease management method in terms of repeatability, reproducibility and other clinically relevant parameters.

\section{REFERENCES}

American Cancer Society. Colorectal cancer. [cited 2016 Apr 21]. Available from: http://www.cancer.org/cancer/ colonandrectumcancer/index.

Bazan V, Bruno L, Augello C, Agnese V, Calò V, Corsale S, et al. Molecular detection of TP53, Ki-Ras and p16INK4A promoter methylation in plasma of patients with colorectal cancer and its association with prognosis: results of a 3-year GOIM (Gruppo Oncologico dell'Italia Meridionale) prospective study. Ann Oncol. 2006;17(Suppl 7):vii84-90.

Cassinotti E, Boni L, Segato S, Rausei S, Marzorati A, Rovera F, et al. Free circulating DNA as a biomarker o colorectal cancer. Int J Surg. 2013;11(S1):S54-7.

Church TR, Wandell M, Lofton-Day C, Mongin SJ, Burger M, Payne SR, et al. Prospective evaluation of methylated SEPT9 in plasma for detection of asymptomatic colorectal cancer. Gut. 2014;63(2):317-25.

Czeiger D, Shaked G, Eini H, Vered I, Belochitski O, Avriel A, et al. Measurement of circulating cell-free dna levels by a new simple fluorescent test in patients with primary colorectal cancer. Am J Clin Pathol. 2011;135(2):264-70. 
De Vos T, Tetzner R, Model F, Weiss G, Schuster M, Distler J, et al. Circulating Methylated SEPT9 DNA in plasma is a biomarker for colorectal cancer. Clin Chem. 2009;55(7):1337-46.

Diaz Jr. LA, Bardelli A. Liquid biopsies: genotyping circulating tumor DNA. J Clin Oncol. 2014;32(6):579-86.

Duffy MJ, Crown J. Precision treatment for cancer: role of prognostic and predictive markers. Clin Rev Clin Lab Sci. 2014;51(1):30-45.

El Messaoudi S, Rolet F, Mouliere F, Thierry AR. Circulating cell-free DNA: preanalytical considerations. Clin Chim Acta. 2013;424:222-30.

Ferlay J, Soerjomataram I, Dikshit R, Eser S, Mathers C, Rebelo $\mathrm{M}$, et al. Cancer incidence and mortality worldwide: sources, methods and major patterns in GLOBOCAN 2012. Int J Cancer. 2015;136(5):E359-86.

Frattini M, Gallino G, Signoroni S, Balestra D, Battaglia L, Sozzi G, et al. Quantitative analysis of plasma DNA in colorectal cancer patients. Ann NY Acad Sci. 2006;1075:185-190.

Frattini M, Gallino G, Signoroni S, Balestra D, Lusa L, Battaglia $\mathrm{L}$, et al. Quantitative and qualitative characterization of plasma DNA identifies primary and recurrent colorectal cancer. Cancer Lett. 2008; 236(2):170-81.

Guadalajara H, Domínguez-Berzosa C, García-Arranz M, Herreros MD, Pascual I, Sanz-Baro R, et al. The concentration of deoxyribonucleic acid in plasma from 73 patients with colorectal cancer and apparent clinical correlations. Cancer Detect Prev. 2008;32(1):39-44.

Hao TB, Shi W, Shen XJ, Qi J, Wu XH, Wu Y, et al. Circulating cell-free DNA in serum as a biomarker for diagnosis and prognostic prediction of colorectal cancer. Br J Cancer. 2014;111(8):1482-9.

Heitzer E, Auer M, Hoffmann EM, Pichler M, Gasch C, Ulz P, et al. Establishment of tumor-specific copy number alterations from plasma DNA of patients with cancer. Int J Cancer. 2013;133(2):346-57.

Instituto Nacional de Câncer. INCA. Tipos de câncer: colorretal. [citad 2016 Apr 21] Available from:

http://www2.inca.gov.br/wps/wcm/connect/tiposdecancer/site/ home/colorretal.
Kondratov AG, Nekrasov KA, Lototska LV, Panasenko GV, Stoliar LA, Lapska YV, et al. Comparative analysis of epigenetic markers in plasma and tissue of patients with colorectal cancer. Biopolym Cell. 2014;30(2):129-34.

Lao VV, Grady WM. Epigenetics and colorectal cancer. Nat Rev Gastroenterol Hepatol. 2011;8(12):686-700.

Lin J, Lin PC, Lin CH, Jiang JK, Yang SH, Liang WY, et al. Clinical relevance of alterations in quantity and quality of plasma DNA in colorectal cancer patients: based on the mutation spectra detected in primary tumors. Ann Surg Oncol. 2014;21(suppl. 4):S680-6.

Lindforss U, Zetterquist H, Papadogiannakis N, Olivecrona H. Persistence of k-ras mutations in plasma after colorectal tumor resection. Anticancer Res. 2005;25(1B):657-62.

Melotte V, Yi JM, Lentjes MH, Smits KM, Van Neste L, Niessen $\mathrm{HE}$, et al. Spectrin repeat containing nuclear envelope 1 and forkhead box protein e1 are promising markers for the detection of colorectal cancer in blood. Cancer Prev Res. 2015;8(2):15764.

Morris V, Kopetz S. Clinical biomarkers in colorectal cancer. Clin Adv Hematol Oncol. 2013;11(12):768-76.

Moulière F, El Messaoudi S, Pang D, Dritschilo A, Thierry AR. Multi-marker analysis of circulating cell-free DNA toward personalized medicine for colorectal cancer. Mol Oncol. 2014;8(5):927-41.

Nicholson BD, Shinkins B, Pathiraja I, Roberts NW, James TJ, Mallett S, et al. Blood CEA levels for detecting recurrent colorectal cancer (review). Cochrane Database Syst Rev. 2015;12(art.CD011134):1-218.

Pedersen SK, Baker RT, McEvoy A, Murray DH, Thomas M, Molloy PL, et al. A two-gene blood test for methylated DNA sensitive for colorectal cancer. PLoS One. 2015;10(4 art. e0125041):1-14.

Schwarzenbach H, Stoehlmacher J, Pantel K, Goekkurt E. Detection and monitoring of cell-free DNA in blood of patients with colorectal cancer. Ann N Y Acad Sci. 2008;1137:190-6.

Spindler KLG, Pallisgaard N, Andersen RF, Brandslund I, Jakobsen A. Circulating free DNA as biomarker and source for mutation detection in metastatic colorectal cancer. PLoS One. 2015;10(4 art.e0108247):1-14. 
Spindler KLG, Appelt AL, Pallisgaard N, Andersen RF, Jakobsen A. KRAS-mutated plasma DNA as predictor of outcome from irinotecan monotherapy in metastatic colorectal cancer. Br J Cancer. 2013;109(12):3067-72.

Spindler KLG, Pallisgaard N, Vogelius I, Jakobsen A. Quantitative cell-free DNA, KRAS, and BRAF mutations in plasma from patients with metastatic colorectal cancer during treatment with cetuximab and irinotecan. Clin Cancer Res. 2012;18(4):1177-85.

Swiderska M, Choromańska B, Dąbrowska E, KonarzewskaDuchnowska E, Choromańska K, Szczurko G, et al. The diagnostics of colorectal cancer. Contemp Oncol. 2014;18(1):1-6.

Tabernero J, Lenz HJ, Siena S, Sobrero A, Falcone A, Ychou $\mathrm{M}$, et al. Analysis of circulating DNA and protein biomarkers to predict the clinical activity of regorafenib and assess prognosis in patients with metastatic colorectal cancer: a retrospective, exploratory analysis of the CORRECT trial. Lancet Oncol. 2015;16(8):937-48.

Takane K, Midorikawa Y, Yagi K, Sakai A, Aburatani H, Takayama T, et al. Aberrant promoter methylation of PPP1R3C and EFHD1 in plasma of colorectal cancer patients. Cancer Med. 2014;3(5):1235-45.

Umetani N, Giuliano AE, Hiramatsu SH, Amersi F, Nakagawa $\mathrm{T}$, Martino S, et al. Prediction of breast tumor progression by integrity of free circulating DNA in serum. J Clin Oncol. 2006;24(26):4270-6.
Wang S, Chen Y, Wu Z. Advances in the medical research and clinical applications on the plasma DNA. Transl Pediatr. 2014;3(2):140-8.

Wong ALA, Lim JS, Sinha A, Gopinathan A, Lim R, Tan CS, et al. Tumour pharmacodynamics and circulating cell free DNA in patients with refractory colorectal carcinoma treated with regorafenib. J Transl Med. 2015;13(57):1-9.

Xu J, Liu XJ, Ge FJ, Lin L, Wang Y, Sharma MR, et al. KRAS mutations in tumor tissue and plasma by different assays predict survival of patients with metastatic colorectal cancer. J Exp Clin Cancer Res 2014,33(104):1-8.

Yörüker EE, Özgür E, Keskin M, Dalay N, Holdenrieder S, Gezer U. Assessment of circulating serum DNA integrity in colorectal cancer patients. Anticancer Res. 2015;35(4):2435-40.

Yoruker EE, Holdenrieder S, Gezer U. Blood-based biomarkers for diagnosis, prognosis and treatment of colorectal cancer. Clin Chim Acta. 2016;455:26-32.

Zhang X, Song YF, Lu HN, Wang DP, Zhang XS, Huang $\mathrm{SL}$, et al. Combined detection of plasma GATA5 and SFRP2 methylation is a valid noninvasive biomarker for colorectal cancer and adenomas. World J Gastroenterol. 2015;21(9):262937.

Received for publication on $20^{\text {th }}$ June 2017 Accepted for publication on $30^{\text {th }}$ August 2017 